\title{
Analysis of Trace Metal Contamination in Pahang River and Kelantan River, Malaysia
}

\author{
Norpadzlihatun Manap ${ }^{1, *}$, Kavitha Sandirasegaran ${ }^{1}$, Noor Shahifah Syahrom ${ }^{1}$, and Amnorzahira Amir ${ }^{2}$ \\ ${ }^{1}$ Department of Construction Management, Faculty of Technology Management and Business, Universiti Tun Hussein Onn Malaysia, \\ 86400 Parit Raja, Batu Pahat, Johor, Malaysia \\ ${ }^{2}$ Faculty of Civil Engineering, Universiti Teknologi MARA, 40450 Shah Alam, Selangor, Malaysia
}

\begin{abstract}
The primary objective of this study is to determine trace metal contamination in environmental samples obtained from Pahang River and Kelantan River, Malaysia which may help to identify the risk of sustainable dredging in these areas. This research also proceeds to compare the trace metal concentration with the National Water Quality Standards of Malaysia, Interim Canadian Sediment Quality Guidelines and Malaysian Food Act 1983 to determine its limits and risks. Samples of water, sediment, snails and fishes were collected and analyzed for $\mathrm{As}, \mathrm{Cu}, \mathrm{Cd}, \mathrm{Cr}, \mathrm{Fe}, \mathrm{Pb}, \mathrm{Ni}, \mathrm{Mn}$, and $\mathrm{Hg}$ by using atomic absorption spectrophotometer. It was found that the concentration of trace metals namely $\mathrm{As}, \mathrm{Cu}, \mathrm{Cd}, \mathrm{Cr}, \mathrm{Pb}, \mathrm{Ni}$, and $\mathrm{Hg}$ in river water, sediment, snail and fish samples in Pahang River were lower than the maximum allowable limits, except for Fe and Mn. In Kelantan River, the concentration of trace metals indicating that it is contaminated with $\mathrm{Fe}, \mathrm{Mn}, \mathrm{Pb}, \mathrm{Cr}, \mathrm{Cu}, \mathrm{Hg}$, and $\mathrm{As}$ as all trace metals exceeded the maximum allowable limits. Negative impacts may arise, and the river may contaminate more in future if there is no proper management to tackle this issue during execution of dredging activities.
\end{abstract}

\section{Introduction}

As the demands for dredging project increases worldwide, it is necessary to handle dredging sustainably $[1,2,3]$. The meaning of sustainability fulfilled when there are implementations or adopts practices and policies that help to balance the environments, social and economic goals [4, 5, 6, 7]. Even though dredging support commerce and economic expansion, healthy aquatic ecosystems and social benefits should be considered during the process of dredge works $[8,9]$.

The entrance of contaminants into the environment due to human and natural activities is one of the most vital issues facing by today's communities [3]. Pollutants have contaminated many of the sediments from rivers and seas worldwide. Usually, waterways located near agricultural, industrial and urban areas. The wastes from these areas will then enter the waterways by surface runoff which will then enter into the biological chain $[7$, $8,10]$.

Trace metals are known as inorganic contaminants and can accumulate for long periods underwater body [10]. Trace metals exist in the environment such as in the water, sediments and living organisms. The toxicity from trace metal contamination is dangerous for the environment mainly marine organisms. The trace metals will accumulate in tissues and organs of aquatic organisms which will then sold for human consumption $[12,13,14]$. These toxic metals with hazardous concentrations may cause long-term health risks to human because the water meant for domestic, agricultural and industrial needs. These toxic effects occur when they exceed standard concentrations [10, 15]. There has been researched performed on the concentration of trace metals in the tissues of marine organisms in recent decades. Fish, shellfish, snails, algae, aquatic plants, and small aquatic mammals are among organisms that were used for research purposes. Fish has been used mostly in research to analyze trace metal contamination because fish consumed as one of the primary sources of protein for humans $[9,16,17]$.

Trace metals will be transferred into sediments by physical, chemical and biological processes [13, 18, 19]. If the contaminated sediments are disturbed especially when there are dredging activities being carried out, living organisms nearby and the water body exposed to toxic contaminants [20].

Trace metals are widely used in automobiles, paints, textile, and mining industries [14, 21]. Certain trace metals such as copper, zinc, iron, manganese, and cobalt play essential roles in biological metabolism at low concentrations. However, chromium, lead, cadmium, and mercury can be toxic even at low concentrations [21, 22]. In the marine environment, small quantities of some trace metals such as nickel, copper, zinc, iron, and manganese are essential for biological systems to function. Nevertheless, when these

* Corresponding author: author@e-mail.org 
trace metals exceed the threshold limit, they can disturb biochemical functions in both humans and animals.

This paper analyzes the current state of trace metal concentrations in the water, sediments, fish and snail samples from Pahang and Kelantan rivers in Malaysia. Major flood events recently occurred at these locations which require the execution of dredging. In December 2014, the states of Pahang and Kelantan had been recorded to be among the worst flooded areas. Many negative impacts faced by the local people and the waterway itself $[31,32]$. For instance, the destruction of property, high sediment deposition in downstream rivers and changes in the geomorphology of Pahang and Kelantan rivers [13]. The main objective of this research is to provide a preliminary record of trace metal contamination in environmental samples obtained from Pahang and Kelantan rivers which may help to determine the risk of dredging in this area. These analyses also proceed to compare the trace metal concentration with the National Water Quality Standards of Malaysia, Interim Canadian Sediment Quality Guidelines (ICSQG) and Malaysia Food Act 1983 to determine the risks of samples taken from Pahang and Kelantan rivers.

\section{Methods}

Water samples, sediment samples, snail samples, and the fish sample collected in 2016 from Pahang River and Kelantan River Malaysia. The sediments were retrieved using Van Veer Grab, and then the sediments were placed in the container. Water samples and fish samples were also collected to investigate their contamination level. Water samples were collected and placed in a beaker while fish samples were placed in polystyrene boxes with ice to preserve the fish samples before sending them to a certified laboratory.

Water, sediment, snail and fish samples were collected once on August 2016 at the downstream of Pahang River near the city of Pekan. Water, sediment, snail and fish samples also collected at the downstream of the Kelantan River near the city of Pengkalan Chepa. Accumulation of trace metals, sediments or wastes mostly will be at downstream of the river. Moreover, downstream areas were chosen because they are located near residential areas, industries, markets, and schools.

All samples were sent to the laboratory a day after the samples were taken from the river. The trace metals namely arsenic (As), copper $(\mathrm{Cu})$, cadmium $(\mathrm{Cd})$, chromium $(\mathrm{Cr})$, iron $(\mathrm{Fe})$, lead $(\mathrm{Pb})$, nickel $(\mathrm{Ni})$, manganese $(\mathrm{Mn})$ and mercury $(\mathrm{Hg})$ analyzed in the samples were determined by a flame atomic absorption spectrophotometer (Hitachi Z-6000). The American Health Public Association (APHA 2005) method used in this analysis.

\section{Results}

\subsection{Results for Pahang River}

Based on the results obtained, it was observed that the sediment sample recorded the highest concentration of trace metals compared to other samples (for $\mathrm{Cr}, \mathrm{Cu}, \mathrm{Fe}$, $\mathrm{Pb}, \mathrm{Mn}$ ). In sediment samples, $\mathrm{Cr}$ recorded a value of $23 \mathrm{mg} / \mathrm{kg}, \mathrm{Cu} 15 \mathrm{mg} / \mathrm{kg}, \mathrm{Fe} 8787 \mathrm{mg} / \mathrm{kg}, \mathrm{Pb} 5.4 \mathrm{mg} / \mathrm{kg}$, Mn $258 \mathrm{mg} / \mathrm{kg}$. For water samples, the values were $\mathrm{Cr}$ $<0.005 \mathrm{mg} / \mathrm{l}, \mathrm{Cu} 0.005 \mathrm{mg} / \mathrm{l}, \mathrm{Fe} 1.03 \mathrm{mg} / \mathrm{l}, \mathrm{Pb}<0.001 \mathrm{mg} / 1$ and $\mathrm{Mn}<0.001 \mathrm{mg} / \mathrm{l}$. Cr content in snail samples was $<0.5 \mathrm{mg} / \mathrm{kg}, \mathrm{Cu} 15 \mathrm{mg} / \mathrm{kg}, \mathrm{Fe} 135 \mathrm{mg} / \mathrm{kg}, \mathrm{Pb}<1 \mathrm{mg} / \mathrm{kg}$ and $\mathrm{Mn} 36 \mathrm{mg} / \mathrm{kg}$. In fish samples, results showed that Fe had the highest concentration compared to other metals which was $5.4 \mathrm{mg} / \mathrm{kg}$, Cr recorded a value of $<0.5 \mathrm{mg} / \mathrm{kg}$, $\mathrm{Cu} 0.5 \mathrm{mg} / \mathrm{kg}, \mathrm{Pb}<1 \mathrm{mg} / \mathrm{kg}$, and $\mathrm{Mn}<0.1 \mathrm{mg} / \mathrm{kg}$. As $\mathrm{Cd}$ and $\mathrm{Hg}$ found to exist in low concentration in all samples. The values do not vary significantly, and similar results obtained which ranged between $<0.005$ to $<0.5$.

It can be concluded that the concentration of $\mathrm{Fe}$, $\mathrm{Cu}, \mathrm{Pb}$, and $\mathrm{Mn}$ were found to be slightly higher compared to other metals in the research samples. The $\mathrm{pH}$ value is an essential indication in the water In order to determine the presence of carbon dioxide and carbonate equilibrium in water [13]. It indicates the presence of hydrogen ions in water. The $\mathrm{pH}$ value in the study area is 7.9 with a temperature of $27.6^{\circ} \mathrm{C}$. The average salinity of river water was $40 \%$, whereas the average surface dissolved oxygen (DO) was $6.07 \mathrm{mg} / 1$. A $\mathrm{pH}$ value of 7.9 may be due to the presence of carbonates of calcium and manganese in the water. These results show that the water is in the alkaline stage.

The trace metal results of the samples obtained compared with the standard limits. The water samples have been compared with the National Water Quality Standards for Malaysia (NWQM) whereas the sediment samples compared with the Interim Canadian Sediment Quality Guidelines (ICSQG). There are no guidelines from Malaysia that can be used to compare the permissible sediment limits $[6,20]$. Based on previous research and studies, it noted that Malaysia includes other countries' references including Canada using (ICSQG) for the sake of comparison with sediment quality $[11,19]$. This Canadian approach involves direct measurement of toxicity of contaminated sediments to a range of aquatic organisms exposed in laboratory tests. Researcher proved ICSQG could be considered as best practice guideline used for sediments $[11,17,22]$. The snail and fish samples were compared with the Malaysia Food Act 1983.

The levels of trace metals in water, sediment, snail and fish samples were found to be low when compared with the permissible levels set by NWQM, ICSQG, and MFA. Only certain trace metals were found to exceed the permissible levels. For example, Iron recorded value of $1.03 \mathrm{mg} / 1$ in the water samples while the permitted level set by NWQM for Iron is only $1 \mathrm{mg} / \mathrm{l}$. The difference is by $0.03 \%$.

In snail samples, manganese exceeded the permissible level set by MFA where the concentration level observed is $36 \mathrm{mg} / \mathrm{kg}$. Based on the analysis done, it can be concluded that the samples from the Pahang River contain certain harmful substances. For example, Iron and Manganese exceeded the permissible limits. 
This clearly shows Pahang River contaminated which may harm environments and humans as well in future.

\subsection{Results for Kelantan River}

The results and details of trace metals in water, sediment, snail and fish samples were analysed in this study. Based on results obtained, it was observed that the sediment sample recorded the highest concentration of trace metals compared to water, fish and snail samples (for $\mathrm{Cr}, \mathrm{Cu}, \mathrm{Fe}$, and $\mathrm{Mn}$ ). In sediment samples, $\mathrm{Cr}$ recorded a value of $12 \mathrm{mg} / \mathrm{kg}, \mathrm{Cu} 1.8 \mathrm{mg} / \mathrm{kg}, \mathrm{Fe}$ $2275 \mathrm{mg} / \mathrm{kg}$, Mn $117 \mathrm{mg} / \mathrm{kg}$. For water samples, the values were $\mathrm{Cr} 0.059 \mathrm{mg} / \mathrm{l}, \mathrm{Cu} 0.050 \mathrm{mg} / \mathrm{l}, \mathrm{Fe} 101 \mathrm{mg} / \mathrm{l}$ and $\mathrm{Mn} 1.78 \mathrm{mg} / \mathrm{l}$. Cr content in snail samples was $<0.5 \mathrm{mg} / \mathrm{kg}, \mathrm{Cu} 0.5 \mathrm{mg} / \mathrm{kg}, \mathrm{Fe} 12.2 \mathrm{mg} / \mathrm{kg}$ and $\mathrm{Mn}$ $2.3 \mathrm{mg} / \mathrm{kg}$. In fish samples, results showed that As had the highest concentration compared to other metals which was $17 \mathrm{mg} / \mathrm{kg}, \mathrm{Cr}$ recorded value of $<0.5 \mathrm{mg} / \mathrm{kg}$, $\mathrm{Cu} 0.5 \mathrm{mg} / \mathrm{kg}$ and $\mathrm{Mn} 2.3 \mathrm{mg} / \mathrm{kg}$. It can be concluded that the concentration of $\mathrm{As}, \mathrm{Fe}, \mathrm{Cu}, \mathrm{Pb}$, and $\mathrm{Mn}$ were found to be slightly higher compared to other metals in the research samples.

The $\mathrm{pH}$ value in the study area is 6.4. This $\mathrm{pH}$ result shows the water from the river is in an acidic stage. The trace metal results of the samples obtained compared with the standards limits. The water samples have been compared with the National Water Quality Standards for Malaysia (NWQM) whereas the sediment samples were compared with the Interim Canadian Sediment Quality Guidelines (ICSQG). There are no guidelines from Malaysia that can be used to compare the permissible sediment limits $[16,20,26]$. Based on previous research and studies, it should be noted that Malaysia includes other countries' references including Canada using (ICSQG) for the sake of comparison with sediment quality $[9,16]$. This Canadian approach involves direct measurement of toxicity of contaminated sediments to a range of aquatic organisms exposed in laboratory tests. Researcher proved ICSQG could be considered as best practice guideline to be used for sediments $[11,17,26]$. The snail and fish samples were compared with the Malaysia Food Act 1983.

The levels of trace metals in water, sediment, snail and fish samples were found to be high when compared with the permissible levels set by NWQM, ICSQG, and MFA. Fe, $\mathrm{Mn}, \mathrm{Pb}, \mathrm{Cr}, \mathrm{Cu}, \mathrm{Hg}$ were found to exceed the permissible levels in the water sample, Fe and $\mathrm{Mn}$ in the sediment sample, As, $\mathrm{Fe}$ and $\mathrm{Mn}$ in snail sample. For example, Iron recorded value of $101 \mathrm{mg} / 1$ in the water samples while the permitted level set by NWQM for Iron is only $1 \mathrm{mg} / 1$. The difference is by $100 \%$.

In snail samples, manganese exceeded the permissible level set by MFA where the concentration level observed is $2.3 \mathrm{mg} / \mathrm{kg}$. Based on the analysis done, it can be concluded that the samples from the Kelantan River contains harmful substances. This clearly shows Kelantan River was contaminated which may harm environments and humans as well in future.

\section{Discussion}

Drastic flood events occurred in 2014 at the states of Pahang and Kelantan. This event has brought massive damage to the surroundings and also substantial damage to the cities' infrastructures. During flood events, much raw sewage which was untreated could enter the Pahang River and Kelantan River which can cause the rivers and surrounding environments to be contaminated [24, 30]. A survey to find out the level of trace metal concentrations in the Pahang River and Kelantan River was conducted. Samples of water, sediment, snail, and fish were collected from the rivers to achieve the objectives of this research. Snails were chosen as one of the samples in this case study because snails move slowly and tend to accumulate poisoned trace metals especially when the snails picked from areas near the contaminated river. Fishes were chosen due to its prominence as a source of protein in the human diet. The levels of metals such as arsenic, copper, manganese, iron, cadmium, chromium, lead, mercury and nickel were measured in this study. Certain trace metals such as $\mathrm{Cd}, \mathrm{Pb}$, As and $\mathrm{Hg}$ was categorized as nonessential trace metals while $\mathrm{Cu}, \mathrm{Zn}, \mathrm{Fe}$, and $\mathrm{Ni}$ were categorized as essential trace metals. Non-essential trace metals are harmful to human health because these trace metals are toxic even in small amounts. These harmful trace metals caused by some human activities, including dredging, which they may be accumulated in the water and living organisms through the food chain. Human health will be at risk when they consume contaminated organisms such as fish. Even though the human body requires some trace metals such as $\mathrm{Cu}, \mathrm{Fe}, \mathrm{Zn}$ and $\mathrm{Ni}$ in trace amounts, excessive levels of these metals will be dangerous to the human body. In this study, the concentration of trace metals such as $\mathrm{As}, \mathrm{Cr}, \mathrm{Cd}, \mathrm{Cu}, \mathrm{Fe}$, $\mathrm{Pb}, \mathrm{Mn}, \mathrm{Ni}$ and $\mathrm{Hg}$ in the water, sediment, snail tissue and fish tissue from the Pahang River and Kelantan River have been discussed.

In this study, the results show that the trace metal concentrations are higher in sediment compared to water, snail and fish samples. Previous researchers have also observed that sediments accumulate more trace metals and hold almost 99 percent of trace metals [27, 28, 29, 30]. Sediment containing high trace metal concentration may be due to the discharge of pollutants into the water. The analysis in Pahang River shows that Fe and Mn recorded high concentration of metals in all samples. Fe found in high concentrations in the samples; $1.03 \mathrm{mg} / \mathrm{L}$ in water samples, $8787 \mathrm{mg} / \mathrm{kg}$ in sediment samples, $135 \mathrm{mg} / \mathrm{kg}$ in snail samples, and $5.4 \mathrm{mg} / \mathrm{kg}$ in fish samples. Such high concentrations of metal can affect human health especially when humans consume aquatic organisms such as fish, clams, and prawns.

, and the main economic activities are fishing, industries and small businesses. These activities probably contributed to the concentration of trace metals found in fish. The trace metals found in snail and fish sample are lower than the standard permitted levels. However, it can still be dangerous to human health as the results showed that the trace metal concentration in fish and snail samples have almost reached the recommended 
limits set by MFA. Arsenic was found in equal amounts set by the MFA which is $1 \mathrm{mg} / \mathrm{kg}$. $\mathrm{Cd}, \mathrm{Ni}$, and $\mathrm{Pb}$ were also almost reaching the standard level. In snail samples, Mn was found in higher levels than the permitted level set by MFA; $36 \mathrm{mg} / \mathrm{kg}$. Cu was also found to exist in higher concentrations in sediment and snail samples compared to fish and water samples. Metabolism, ecological needs and characteristics could be the contributing factors to the difference of the trace metal concentrations in the analyzed samples. These trace metals might be harmful and sufficient to cause toxicological effects on human health when they consume fish as part of their daily diet.

This paper also analyzed trace metals that found in water, sediment, fish and snail sample from Kelantan River. This study revealed that sediments from the Kelantan River accumulated high concentration of heavy metal compared to other samples. Fe and $\mathrm{Mn}$ were analyzed and have the highest concentration in water, sediment, and snail samples. While only Fe metal was high in the fish sample.

The results also have been compared with the standards limits, and it is observed that the concentration of $\mathrm{Mn}, \mathrm{Cr}, \mathrm{Fe}, \mathrm{Pb}$, and $\mathrm{Cu}$ exceed the limits in water sample when compare with the National Water Quality Standard for Malaysia (NWQSM). The concentration is $1.78 \mathrm{mg} / \mathrm{l}, 0.059 \mathrm{mg} / \mathrm{l}$ and $101 \mathrm{mg} / \mathrm{l}$ respectively. $\mathrm{Fe}$ metal of sediment sample exceed the standard limit set by Interim Canadian Sediment Quality Guidelines, and the amount is $2275 \mathrm{mg} / \mathrm{kg}$ while the standard set is only $35 \mathrm{mg} / \mathrm{kg}$. As and Fe were observed exceed the standard limits in snail sample. The difference between the sample and the standards set is by $16 \%$ for As metal while for $\mathrm{Fe}$ is $11.6 \%$. Other metals all are lower than the recommended limits.

\section{Conclusion}

In general, this paper discussed on contaminations of trace metals in samples collected from Pahang River of Malaysia. The laboratory experiment was carried out on the water, sediment, snail and fish samples to obtain the results of $\mathrm{As}, \mathrm{Cu}, \mathrm{Cr}, \mathrm{Fe}, \mathrm{Hg}, \mathrm{Ni}, \mathrm{Pb}, \mathrm{Mn}$ and $\mathrm{Cd}$ concentrations. The results from Pahang River show that Fe exceeded the standards permissible limits in water, sediment, snail and fish samples. While $\mathrm{Mn}$ concentration also above the standards in snail and fish sample. In Malaysia, fish consumption per day is 0.006 $\mathrm{kg}$. The difference of $\mathrm{Mn}$ concentration in the fish sample and Malaysian Food Act 1983 by percentage is 3.51. This clearly shows a negative sign that the fish in the Pahang River contaminated with $\mathrm{Mn}$ and harmful to human health.

On the other hand, the concentration of trace metals may become higher via the bioaccumulation process. Therefore, it suggested that monitoring studies and suitable action was taken in order to handle and assess the risks of trace metal contamination towards humans. This study is also performed to identify the contamination of trace metals in the water, sediment, snail and fish sample that collected from Kelantan River.
The laboratory experiment was carried out on water, sediment, snail and fish samples to obtain the results of $\mathrm{As}, \mathrm{Cu}, \mathrm{Cr}, \mathrm{Fe}, \mathrm{Hg}, \mathrm{Ni}, \mathrm{Pb}, \mathrm{Mn}$ and $\mathrm{Cd}$ concentrations. It observed that the concentration of trace metals such as $\mathrm{Fe}, \mathrm{Mn}, \mathrm{Pb}, \mathrm{Cr}, \mathrm{Cu}$ and $\mathrm{Hg}$ in water sample exceed the permissible limits. In sediment, only $\mathrm{Fe}$ exceeded the permissible limit, while in snail sample $\mathrm{As}$ and $\mathrm{Fe}$ exceeded the permissible limits. To conclude, there is a must for constant monitoring of the rivers in Malaysia as trace metal is hazardous to human and the surrounding environments. The concentration of trace metals may become higher via the bioaccumulation process and affect human's life [31].

This research was performed to fulfill the requirements of a research grant (Vote no. R063). Acknowledgments are given to the Ministry of Higher Education Malaysia and the Office for Research, Innovation, Commercialization and Consultancy Management, Universiti Tun Hussein Onn Malaysia for their support during the publication of this paper.

\section{References}

1. N. Manap and N. Voulvoulis, Applied Mechanics and Materials, 567, pp. 50-55, 2014.

2. N. Manap, K.Y. Tan and N. Shahrom, IOP Conference Series: Earth and Environmental Science, 109, 012026, 2017.

3. N. Manap, N.H. Mohd Noh and N. Syahrom, IOP Conference Series: Earth and Environmental Science, 109, 012011, 2017.

4. N. Manap, N.I. Muhamad and K., Sandirasegaran, Materials Science Forum, 889 pp. 261-264, 2017.

5. N. Manap, N. Jeyaramah, and N. Syahrom, IOP Conference Series: Earth and Environmental Science, 109, 012027, 2017.

6. N. Manap, Y.K. Goh and N. Syahrom, IOP Conference Series: Earth and Environmental Science, 109, 012008, 2017.

7. J. B. Edward, E. O. Idowu, J. A. Oso, O. R. Ibidapo. International Journal Of Environmental Monitoring and Analysis. 1(1), pp. 27-33, 2013.

8. J. Irwandi, and O. Farida, International Food Research Journal, 16, pp. 105-112, 2009.

9. K. Loska and D. Wiechuta, Journal of Chemosphere, 51, pp. 723-733, 2003.

10. J. H. Dong, M. Yu, Z. F. Bian, Y. Wang, C. L. Di, Journal of Environment Earth Science, 62(1), pp. 127-137, 2011.

11. A. Demirak, F. Yilmaz, A. L. Tuna, and N. Ozdemir, Journal of Chemosphere, 63, pp. 14511458, 2006.

12. A. Gopinath, S.M. Nair, N.C. Kumar and D. Pamalal, Journal of Environment Earth Science., 59, pp. 1245-1266, 2010.

13. M. Tuzen, Journal of Food Chemistry, 80(1), pp 119-123, 2013. 
14. H. Beldi, F. Gimbert, S. Maas, R. Scheifler and N. Soltani, African Journal of Agricultural Research, 1(4), pp. 85-90, 2006.

15. P. Sivaperumal, T. V. Sankar and P. G. V. Nair, Journal of International Standards Food Chemistry, 102, pp. 612-620, 2007.

16. A. B. Odaiho, 1, Stirling Holden Publishers, Ibadan, Nigeria (1997)

17. N. Ghannem, D. Gargouri, M.M. Sarbeji, C. Yaich, and C. Azri, Journal of Environment Earth Science, 72, pp. 3419-3427, 2014.

18. M. B. Lohani, A. Singh, D.C. Rupainwar, D.N. Dhar, Journal of Environmental Monitoring Assessment. 147, pp. 253-263, 2008.

19. K. Sandirasegaran and N. Manap, Jurnal Teknologi, 73(3): 139-143,2016.

20. J.N. Meegoda and R. Perera, Journal of Hazardous Materials, 113, pp. 128-136, 2001.

21. Y., Keskin, R. Baskaya, O. Ozyaral, T. Yurdun, N. E. Luleci, and O. Hayran, Bulletin of Environmental Contamination and Toxicology, 78, No. 3-4, pp. 258-261, 2007.

22. M.K.A. Kamarudin, M.E. Toriman, M. H. Rosli, H. Juahir, A. Azid, S.F. Mohamed Zainuddin, N.A. Abdul Aziz, and W.N.A. Sulaiman, Mitigation and Adaptation Strategies for Global Change: 1-16, 2014.

23. A.G. Aminuddin, K.C. Chun, S.L. Cheng, and N.A. Zakaria. International Jornal of River Basin Management, DOI: 10.1080/15715124. 2012. 680022, 2012.

24. Berita Harian Online. Terkini : Banjir di Kelantan, Terengganu, Pahang tambah buruk, Selasa Disember 23, 2014 (2015)

25. M.C. Ong and B.Y. Kamaruzzaman, American Journal of Applied Sciences, 6(7), pp1418-1423 ,2009.

26. E.I. Adeyeye, International Journal of Environmental Studies, 45, pp. 231-240, 1994.

27. E.I. Adeyeye, Journal of Science and Industrial Research, 2, pp. 36-44, 1996.

28. O. J. Aderinola, E. O. Clarke, O. M. Olarinmoye, V. Kusemiju and M. Anatekhai, Journal of Agriculture \& Environmental Science, 5(5), pp. 609-617, 2009.

29. H. J. Bowler, Journal of Environment Science of Technology, pp. 683-687, 1979.

30. K. Sandirasegaran and N. Manap, Jurnal Teknologi, 73(3): 139-143, 2016.

31. N. Manap, R.A.A., Raja Bedali, K. Sandirasegaran, M.A.N. Masrom, and M.Y. Yahya, Jurnal Teknologi, 78(3), pp. 87-92, 2016.

32. N. Manap, S. Polis, K. Sandirasegaran, M.A.N. Masrom, K.C. Goh, and M.Y. Yahya, Jurnal Teknologi, 78(3), pp. 111-116, 2016. 